\title{
Molecular studies of forage prickly-pear cactus from the semiarid of Pernambuco StateBrazil
}

\author{
M. C. C. P. de Lyra ${ }^{1}$, M. L. R. B. da Silva ${ }^{2}$, A. C. E. S Mergulhão ${ }^{3}$, C. Mondragon-Jacobo ${ }^{4}$, E. Martínez-Romero ${ }^{5}$ \\ ${ }^{1}$ Laboratorio de Genômica. Instituto Agronômico de Pernambuco-IPA. Av. Gal San Martin 1371 Bonji, Recife, Pernambuco, Brazil. ${ }^{2}$ Fellowship Pos- \\ doctor PNPD/CAPES. Laboratorio de Genômica, Instituto Agronômico de Pernambuco-IPA. Av. Gal San Martin 1371 Bonji, Recife, Pernambuco, Brazil. \\ ${ }^{3}$ Laboratorio de Genômica, Instituto Agronômico de Pernambuco-IPA. Av. Gal San Martin 1371 Bonji, Recife, Pernambuco, Brazil. Instituto Nacional de \\ Investigaciones Forestales, Agrícolas y Pecuarías-INIFAP. Av. Luis Pasteur 414, 1er. piso, Valle Alameda, Queretaro- Queretaro-México. ${ }^{5}$ Ecological \\ Genomics Program, Research Group Environmental and Symbiotic Microbiology Universidad Nacional Autonóma de México, Centro de Ciencias \\ Genómicas Av. Universidad s/n Col. Chamilpa 62210, Cuernavaca, Morelos, México.
}

\section{ARTICLE INFO}

Article history:

Received on: 04/11/2014

Revised on: 11/01/2015

Accepted on: 17/02/2015

Available online: 27/04/2015

Key words:

Cactaceae, tropical plants, Nopalea, Opuntia, Taxonomy, ITS.

\begin{abstract}
The cultivation of forage cactus is of great economic interest in Brazil, due to its then importance for nutrition animal. This crop had been studied for many years but the advent of molecular biology has greatly contributed to shed light on its phylogeny. Twenty-eight prickly pear cactus plants (Opuntia and Nopalea) - from Brazil were analyzed using the ribosomal marker ITS (internal transcribed space regions) of rRNA ribosomal gene. Three prickly pear cactus varieties are used the forage in Northeastern Brazil: var. palma gigante (Opuntia ficus-indica), var. palma redonda (Opuntia sp.), var. miúda (Nopalea cochenillifera or Opuntia cochenillifera). The DNA was extracted from leaves and the ITS1 and ITS2 regions of all plants amplified and sequenced. Results showed que the ITS marker is very efficient to investigate the species studied and examine the level of the genus cactus plants. Interestingly, the species Nopalea cochenillifera when submitted to the NCBI its designation was changed to Opuntia cochenillifera, however, the organisms continues the Nopalea cochenillifera. These plants may show high degree of apomixis, vegetative propagation, ploidy and the high inter and intra-specific hybridization capacity. Plant systematic and phylogenetic studies are based on morphological and molecular mainly characteristics. The ribosomal ITS rRNA markers 1-2 have great ability to characterize species of prickly pear cactus in this work. Additional studies with other phylogenetic markers will deepen the understanding of the phylogeny of these species.
\end{abstract}

\section{INTRODUCTION}

Some species of the genera Opuntia and Nopalea of the Cactaceae family [1] are cultivated and are essential in the diet of human beings and animal. Opuntia was introduced in Brazil towards the end of the nineteenth century and is the most important forage crop animals in the Northeast region of Brazil. Prickly pear cactus is cultivated in an area of approximately 500 thousand hectare in northeastern Brazil, Pernambuco and mainly in Alagoas State. In the semiarid region of Pernambuco the lack of water is partial or complete and high quality fodder production is unsustainable. The only suitable crop to feed animals during the dry season under these conditions is prickly pear cactus.

\footnotetext{
* Corresponding Author

E-mail: mccatanho@gmail.com
}

Three cactus varieties are used the forage in Northeastern Brazil: var. palmagigante (Opuntiaficus indica), var. palmaredonda (Opuntia sp.) and var. miúda (Nopalea cochenillifera). The high capacity of prickly pear cactus is vegetative propagation has contributed to its widespread distribution, even to the extent of becoming a weed [2-5]. In secondary diversification areas of introduction, the genotypic and phenotypic characteristics of Opuntia were modified [6]. It seems that changes in some genes may lead to phenotypic differences such as presence and absence of thorns [7], phenotypic variation may occur in relation to polyploidy [8] and plant hybridization. The taxonomical and evolutionary studies based on morphology is prickly pear cactus has been hampered by these difficulties [910]. The advent of molecular biology has created new tools that help to enhance the characterization of these banks in the world. 
The use of morphological characters alone to evaluate the germplasm bank makes evaluations difficult and the genetic markers using DNA have facilitated the classification within the genus Opuntia [11]. A widely used method is based on the internal transcribed spacer of nuclear ribosomal genes (nrITS) for phylogenetic analysis indicated that Opuntiaficus indica should not be considered polyphyletic (the group that does not include the common ancestor of all individuals) when derived from multiple lines. Report of Baldwin [12] que the sequencing of the ITS region has one potential source of the the nuclear DNA characterization for phylogenetic reconstruction in plants.

The aim of this study was to characterize some of prickly pear cactus accessions that exist in the germplasm bank of two regions of the state of Pernambuco in semiarid which are based on internal transcribed spacer sequences.

\section{MATERIAL AND METHODS}

Twenty eight plants of the species Opuntioideae were provided by the germplasm bank of the Agronomic Institute of Pernambuco (IPA); the plants were collected from the experimental fields in Arcoverde and Sertânia municipality (Table $1 \mathrm{a}$ and $1 \mathrm{~b}$ ). The samples were taken from the modified leaves and placed tubes with silica to lyophilize the whole tissue for further analyses. Total genomic DNA was isolated from $20 \mathrm{mg}$ of plant tissue lyophilized and macerated in liquid nitrogen using a procedure of the GenomicPrep ${ }^{\mathrm{TM}}$ kit from GE Healthcare and following the user's protocol. The ITS region of nuclear ribosomal DNA was amplified using primer specific for ITS1 and ITS2 regions were amplified as described by [13]. The primers used were ITS1 (5'-TCCGTAGGTGAACCTGCGG-3') and ITS4 (5'TCCTCCGCTTATTGATATGC-3'). The PCRs were carried out in $50 \mu \mathrm{l}$ solution containing $(1.5 \mathrm{mM}) \mathrm{MgCl}_{2},(0.25 \mathrm{mM}) \mathrm{dNTPs}$ mix, DMSO (10\%), (0.4 $\mu \mathrm{M})$ ITS1, $(0.4 \mu \mathrm{M})$ ITS4, Taq buffer 10X (10\%), Taq polymerase Invitrogen (1U). The genomic DNA concentrations varied from $10 \mathrm{ng}$ to $40 \mathrm{ng}$. The $30 \mathrm{X}$ PCR cycles were: $96^{\circ} \mathrm{C}$ for $30 \mathrm{~s}$; annealing at $58^{\circ} \mathrm{C}$ for $30 \mathrm{~s}$, extension step at $72^{\circ} \mathrm{C}$ of $45 \mathrm{~s}$ and a final extension step at $72^{\circ} \mathrm{C}$ of $10 \mathrm{~min}$. The vegetable prickly pear cactus material has a lot of mucilage, a material that has loads of secondary metabolites such as phenols which greatly complicates the extraction of genomic DNA with a high degree of purity.

In view of this, it was necessary to use the NESTEDPCR technique for obtaining amplicons of the ITS region. For this, the bands were cut from the gel using QIA quick Gel Extraction Kit (Qiagen, Hilden, Germany). A volume of $5 \mu 1$ of the purified product was reamplified using the same reagents and cycling conditions for PCR. The DNA fragments were visualized under $\mathrm{UV}$ in $0.8 \%$ agarose gel using SybrGold (Invitrogen) using $1 \mathrm{~Kb}$ Plus Invitrogen as marker. The nested-PCR was performed three times to a volume of $100 \mathrm{ul}$ and after checking the DNA products in agarose gels, a volume of 100 ul of amplified product was mixed with using of $8 \mathrm{ul}$ ammonium acetate $7.5 \mathrm{M}, 208 \mathrm{ul} 100 \%$ ethanol and centrifuged at $10000 \mathrm{rpm}$ for $45 \mathrm{~min}$. to $20^{\circ} \mathrm{C}$. Then, cold $70 \%$ ethanol was added, centrifuged for $10 \mathrm{~min}$. at $4000 \mathrm{rpm}$ and then the supernatant was discarded and the microtube was reversed leaving dry overnight. The pellet was re-suspended DNA purified in $30 \mathrm{ul}$ of sterile ultrapure water and stored at $-20^{\circ} \mathrm{C}$ until sequenced. These products of the of region ITS1 and ITS 2 purified and sent for sequencing by the Sanger method in an automatic Applied Biosystem sequencer using Macrogen. BioEdit 7.0.9 (http://www.mbio.ncsu.edu/BioEdit) was used for alignments, excluding the end of $18 \mathrm{~S}$ ribosomal gene and the beginning of $26 \mathrm{~S}$ rDNA and then cut to $619 \mathrm{pb}$. Online blast at the NCBI website was used for analysis. The evolutionary history was inferred using the Neighbor-Joining method (NJ)[14]. The optimal tree with the sum of branch length $=0.24113564$ is shown. The percentage of replicate trees in which the associated taxa clustered together in the bootstrap test (1000 replicates) are shown next to the branches Felsenstein[15].

The phylogenetic tree was linearized assuming equal evolutionary rates in all lineages [16]. The tree is drawn to scale, with branch lengths in the same units as those of the evolutionary distances used to infer the phylogenetic tree. The evolutionary distances were computed using the Tamura-Nei method [17] and are in the units of the number of base substitutions per site. Codon positions included were $1 \mathrm{st}+2 \mathrm{nd}+3 \mathrm{rd}+$ Noncoding. All positions containing alignment gaps and missing data were eliminated only in pair wise sequence comparisons (Pairwise deletion option). There were a total of 597 positions in the final dataset. Phylogenetic analyses were conducted in MEGA4.0 (http://www.megasoftware.net/) [18].

\section{RESULTS AND DISCUSSION}

The phylogenetic tree (Fig.1) obtained from the analysis of ITS 1 and 2 from 28 Brazilian accessions and compared with six species of Opuntias in GenBank. Clustal X Software was used to align the lengths to the ITS sequences by BioEdit Program ranged from $583-653 \mathrm{bp}$ and the ITS sequence phylogenetic tree construted with MEGA program using inferred NJ tree and Tamura-Nei short distances based on all pairwase comparison of ITS1, 5.8S and ITS2. The sequence of the $5.8 \mathrm{~S}$ was well conserved with the length of $162 \mathrm{bp}$. The average A, T, C, G ratio was $20.5 ; 15,5 ; 33.2 ; 30.9$. The ITS had high $\mathrm{G}+\mathrm{C}$ content consistent with earlier observations in the other plant taxa $[12 ; 19]$. As out group it used AY181575.1 Pachycereus lepidanthus isolate tcsn. The alignable portions between the in group and out group did not provide any information to resolve in group phylogeny. Interestingly, the species Nopalea cochenillifera when submitted to the NCBI its designation was changed to Opuntia cochenillifera however as organisms continues as Nopalea cochenillifera. All Nopalea here studied before were characterized by their morphological characteristics in Brazil. The Fig. 1 shows five major clusters. The first cluster include nine accessions: AM946670.1, AM946671.1 and AM946668.1 with 100\% similarity. With a smaller similarity, AM946666.1 and AM946667.1 were also found in this cluster. 


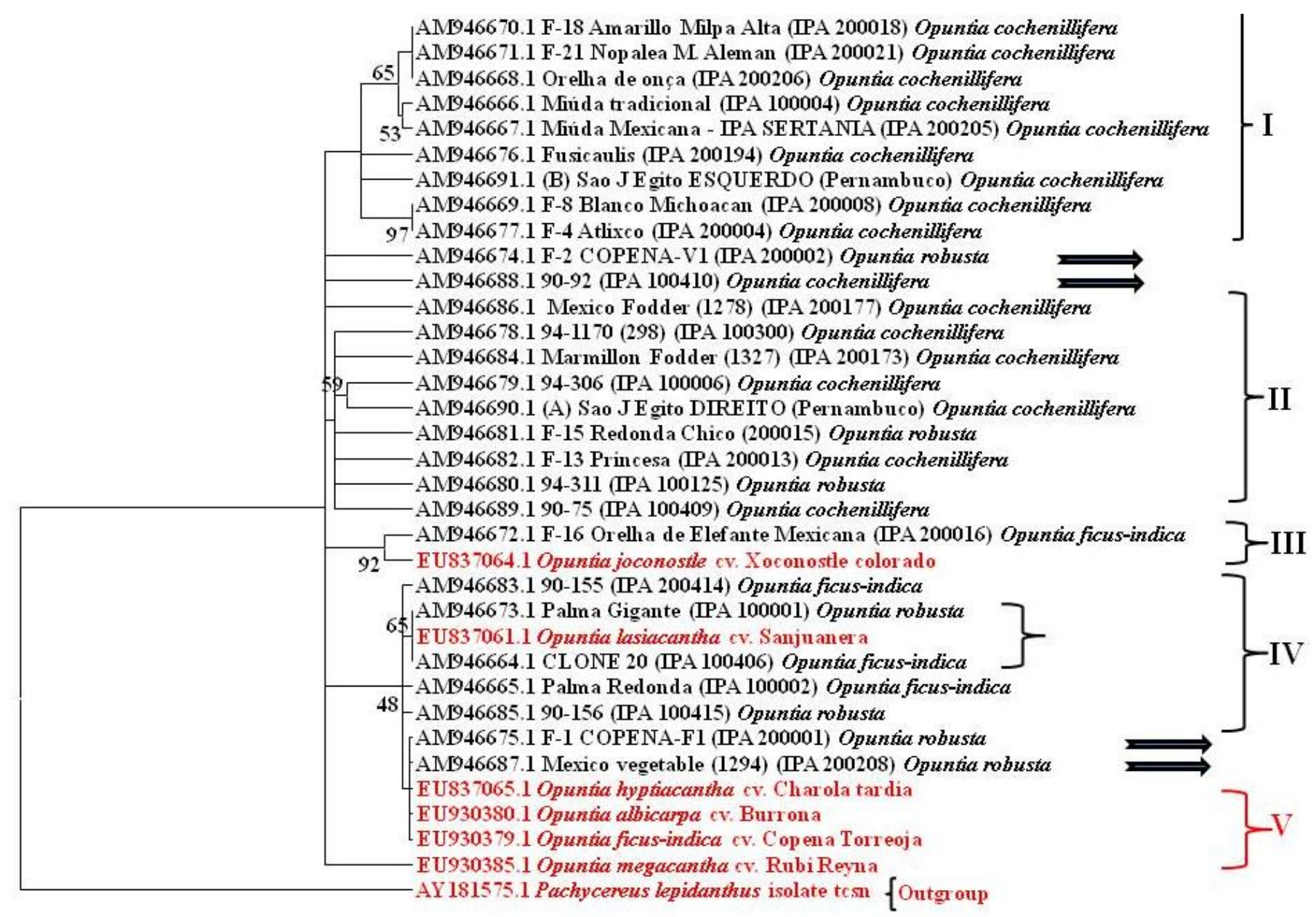

30350.0300 .0250 .0200 .0150 .0100 .0050 .000

Fig. 1: Phylogenetic tree based on ITS sequences from Opuntiaficus indica and O.cochenillifera using Neighbor-Joining (NJ) with Tamura-Nei and 1000 bootstrap tests.

Table 1a: Species of the Opuntias tested, species, author, GenBank accession numbers, voucher and specimen for ITS sequences.

\begin{tabular}{|c|c|c|c|c|}
\hline Species/bases pair (bp) & Author & GenBankAcession no. & Voucher & Specimen/no \\
\hline Opuntiaficus indica/623bp & This study & AM946664 & ArcoverdeGermplasm Bank & clone-20 IPA100406 \\
\hline Opuntia ficus-indica/643bp & This study & AM946665 & ArcoverdeGermplasm Bank & Palma Redonda IPA100002 \\
\hline Opuntia cochenillifera/615 bp & This study & AM946666 & ArcoverdeGermplasm Bank & Miúda Redonda IPA100004 \\
\hline Opuntia cochenillifera/653 bp & This study & AM946667 & SertâniaGermplasm Bank & Miuda mexicana IPA Sertânia IPA200205 \\
\hline Opuntia cochenillifera/647 bp & This study & AM946668 & ArcoverdeGermplasm Bank & Orelha de Onça IPA 200206 \\
\hline Opuntia cochenillifera/607 bp & This study & AM946669 & ArcoverdeGermplasm Bank & F8-Blanco Michoacan IPA200008 \\
\hline Opuntia cochenillifera/642 bp & This study & AM946670 & ArcoverdeGermplasm Bank & F18-Amarillo Milpa Alta IPA200018 \\
\hline Opuntia cochenillifera/641 pb & This study & AM946671 & ArcoverdeGermplasm Bank & F21-Nopalea M. Aleman IPA200021 \\
\hline Opuntia ficus-indica/616 bp & This study & AM946672 & ArcoverdeGermplasm Bank & Orelha de elefante Mexicana IPA200016 \\
\hline Opuntia robusta/618 bp & This study & AM946673 & ArcoverdeGermplasm Bank & Palma Gigante IPA100001 \\
\hline Opuntia robusta/613 bp & This study & AM946674 & ArcoverdeGermplasm Bank & COPENA-V1 IPA200002 \\
\hline Opuntia robusta/653 bp & This study & AM946675 & ArcoverdeGermplasm Bank & COPENA-F1 IPA200001 \\
\hline Opuntia cochenillifera/626 bp & This study & AM946676 & SertaniaGermplasm Bank & FUSICAULIS IPA200194 \\
\hline Opuntia cochenillifera/635 bp & This study & AM946677 & SertaniaGermplasm Bank & F4-Atlixco IPA200004 \\
\hline Opuntia cochenillifera/594 bp & This study & AM946678 & SertaniaGermplasm Bank & 94-1170 (298) IPA100300 \\
\hline Opuntia cochenillifera/646 bp & This study & AM946679 & SertaniaGermplasm Bank & 94-306 IPA100006 \\
\hline Opuntia robusta/629 bp & This study & AM946680 & SertaniaGermplasm Bank & 94-311 IPA100125 \\
\hline Opuntia robusta/583 bp & This study & AM946681 & SertaniaGermplasm Bank & F15-Redonda Chico IPA200015 \\
\hline Opuntia cochenillifera/602 bp & This study & AM946682 & SertaniaGermplasm Bank & F13-Princesa IPA200013 \\
\hline Opuntia ficus-indica/652 bp & This study & AM946683 & ArcoverdeGermplasm Bank & 90-155 IPA200414 \\
\hline Opuntia cochenillifera/643 bp & This study & AM946684 & ArcoverdeGermplasm Bank & (1327) MarmillonFodder IPA200173 \\
\hline
\end{tabular}


Table 1b: Continued Species of the Opuntias tested, species, author, GenBank accession numbers, voucher and specimen for ITS sequences.

\begin{tabular}{|c|c|c|c|c|}
\hline Species/bases pair (bp) & Author & $\begin{array}{l}\text { GenBank } \\
\text { Acession no. }\end{array}$ & Voucher & Specimen $/ \mathbf{n}^{\circ}$ \\
\hline Opuntia robusta/629 bp & This study & AM946685 & ArcoverdeGermplasm Bank & 90-156 IPA100415 \\
\hline Opuntia cochenillifera/658 bp & This study & AM946686 & ArcoverdeGermplasm Bank & (1278) MexicoFodder IPA200177 \\
\hline Opuntia robusta/645 bp & This study & AM946687 & ArcoverdeGermplasm Bank & (1294) Mexico vegetable IPA200208 \\
\hline Opuntia robusta/654 bp & This study & AM946688 & ArcoverdeGermplasm Bank & 90-92 IPA100410 \\
\hline Opuntia cochenillifera/642 bp & This study & AM946689 & ArcoverdeGermplasm Bank & 90-75 IPA100409 \\
\hline Opuntia cochenillifera/652 bp & This study & AM946690 & São josé do Egito & DIREITO \\
\hline Opuntia cochenillifera/646 bp & This study & AM946691 & São josé do Egito & ESQUERDO \\
\hline Opuntia joconostle /665 bp & Luna-Paez et al, 2008 Unpublished & EU837064 & Germplasmbank CRUCEN-UACH & Xoconostle colorado \\
\hline Opuntia lasiacantha/665 bp & Luna-Paez et al, 2008 Unpublished & EU837061 & Germplasmbank CRUCEN-UACH & Sanjuanera \\
\hline Opuntia hyptiacantha/667 bp & Luna-Paez et al, 2008 Unpublished & EU837065 & Germplasmbank CRUCEN-UACH & Charola tardia \\
\hline Opuntia albicarpa/678 bp & $\begin{array}{l}\text { Valadez-Moctezuma et al, } 2008 \\
\text { Unpublished }\end{array}$ & EU930380 & Germplasmbank CRUCEN-UACH & Burrona \\
\hline Opuntia ficus-indica/686 bp & $\begin{array}{l}\text { Valadez-Moctezuma et al, } 2008 \\
\text { Unpublished }\end{array}$ & EU930379 & Germplasmbank CRUCEN-UACH & CopenaTorreoja \\
\hline Opuntia megacantha/541 bp & $\begin{array}{l}\text { Valadez-Moctezuma et al, } 2008 \\
\text { Unpublished }\end{array}$ & EU930385 & Germplasmbank CRUCEN-UACH & Rubi Reyna \\
\hline Pachycereuslepidanthus/751 bp & Arias et al 2003 & AY181575 & JardinBotanico, UNAM & isolatetcsn \\
\hline
\end{tabular}

The species AM946669.1 and AM946677.1 showed $100 \%$ of similarity and bootstrap values above $97 \%$ are considered to be significantly supported. Two monophyletic branches formed by the accessions AM946676.1 and AM946691.1 were detected. In cluster II, the majority of species behaved as monophyletic branches and the species AM946681.1 and AM946680.1 appeared as Opuntia robusta. The clusters III, the species AM946672.1 grouped EU837064.1 Opuntia joconostle cv. Xoconostle colorado. This species Opuntia ficus-indica grouped in cluster IV (AM946683.1, AM946664.1, AM946665.1). All the NCBI species were grouped in cluster V. Plant systematic and phylogenetic studies are based mainly on morphological and molecular characters.

As has been previously observed in plants [20], we found that the phenotype is not a straight function of the genotype, but undoubtedly the genotypic characterization should be investigated. There are major incongruences in taxonomic studies of Opuntia due to phenotypic variations caused mainly by their high inter and intra specific hybridization capacity, polyploidy, vegetative and sexual reproduction and to the high apomixis rate, which allows the occurrence of hybrids between species [21]. The subfamily Opuntioideae has been challenging the generic and specific classification with few natural exomorphic (external appearance) traits and the existence of asexually propagated hybrids, hampering the recognition of this taxon considerably [6;22]. The phenotypic variability between lines of the genus Opuntioid may result in convergence due to difficulties encountered by taxonomists to examine the morphology of cactaceas especially the genera Opuntia and Nopalea, resulting in controversial generic circumscription. We also observed that while Opuntia and Nopalea can be separated into two different clades there are exceptions.

\section{CONCLUSION}

The rDNA ribosomal ITS 1 and ITS 2 markers have great ability to characterize species of forage cactus in this work and proved adequate to separate the accesions studied according to our classified botanically as Nopalea cochenillifera or Opuntia cochenillifera, Opuntia robusta and Opuntia ficus-indica which were grouped similarly by morphological traits and by the molecular analysis..

\section{ACKNOWLEDGEMENTS}

The authors thank Lopez, E, Becerra, S, Yañez, J., Gaytan, P from the Instituto de Biotecnologia, UNAM for preparing the oligonucleotides. They are grateful to the Secretary of the Laboratório de Ecologia Genómica Lucila Lulo Ochoa for her enormous help with the paperwork and to Jorge Muñoz Garcia and Martin Garcia Solis whose endeavour made the everyday work of this research a lot easier.

\section{REFERENCES}

1. Santos DC, Farias I, Lira MA, Santos MVF, Arruda GP, Coelho RSB, Dias FM, Melo JN. Manejo e utilização da Palma Forrageira (Opuntia e Nopalea) em Pernambuco. Recife: IPA. IPA Documentos 30 [Internet]. 2006 [cited 2014 Jul 22]. Available from: http://www.ipa.br/publicacoes_tecnicas/Pal01.pdf

2. Mandujano MC, Montaña C, Méndez I, Golubov J. The relative contributions of sexual reproduction and propagation in Opuntia rastrera from two habitats in the Chihuahuan Desert.Journal of Ecology.1998; $86 \quad$ (6):911-921.doi: $10.1046 /$ j.13652745.1998.00308.x..

3. Griffith MP. A new Chihuahuan Desert prickly pear, Opuntia x rooneyi.Cactus and Succulent Journal [Internet]. 2001 [cited 2014 Aug 12];73:307-310. Available from:http://cssainc.org/index.php/directory/articles/

4. Griffith MP. Experimental hybridization in northern Chihuahuan desert region Opuntia, Rancho Santa Ana Botanic Garden [Internet]. 2001 [cited 2014 Sep 14]; 20: 37-42.Available from: http://2001.botanyconference.org/section12/abstracts/243.shtml

5. Griffith MP. Using molecular data to elucidate reticulate evolution in Opuntia.Madroño [Internet]. 2003 [cited 2014 Aug 12]; 50:162-169. Available from: http://calbotsoc.org/madrono.html

6. Benson LH. The cacti of the United States and Canada. Stanford University Press, Stanford, California: US;1982.

7. Mondragon-Jacobo C. Cactus Pear Domestication and Breeding. Plant Breeding Rev. [Internet]. 2001 [cited 2014 Sep 14]:135165.Available from: http://www.wiley.com/WileyCDA/ WileyTitle/productCd-1118100492.html

8. Kiesling, R. Orígen, Domesticación y Distribución de Opuntia ficusindica.Journal of the Professional Association for Cactus 
Development [Internet]. 1999 [cited 2014 Aug 12]; 3: 50-59. Available from: http://www.jpacd.org/downloads/Vol3/RAC_2.pdf

9. Wang X, Felker P, BurowDM, PatersonHA. Comparison of RAPD marker patterns to morphological and physiological data in the classification of Opuntia accessions. Journal of the Professional Association for Cactus Development [Internet]. 1998 [cited 2014 Aug Availablefrom:http://jpacd.org/downloads/Vol3/BGICV_1.pdf

10. Luna-Paez A, Valadez-Moctezuma E, Barrientos-Priego AF, Gallegos-Vázquez C. Caracterización de Opuntiaspp. mediante Semilla con marcadores RAPD e ISSR y su posible uso para diferenciación.Journal of the Professional Association for Cactus Development [Internet]. 2007 [cited 2014 Aug 12]; 9: 43-59. Available from:http://www.jpacd.org/downloads/Vol9/V9P43-59.pdf

11. Andersen JR,Lübberstedt T. Functional markers in plants.Trends in Plant Sciences.2003. 8: 554-560.doi: 10.1016/j.tplants.2003.09.01.

12. Baldwin BG. Phylogenetic utility of the internal transcribed spacersos nuclear ribosomal DNA in plants: An Exemplefrom the composite. Molecular Phylogenetics and Evolution [Internet] 1992 [cited $2014 \quad$ Sep 14$] ; \quad 1: 3-16$. Available from:http://ucjeps.berkeley.edu/pdfs/Baldwin_1992_both_sides1.pdf

13. White TJ, Bruns T, Lee S, Taylor J. Amplification and direct sequencing of fungal ribosomal RNA genes for Phylogenetics. In: PCR protocols, a guide to methods, and, applications, eds. M.A Innis, D.H. Gelfand, J.J. Sninsky, and, T.J. White. San Diego: Academic Press. 1990.p.315-322.

14. Saitou N, Nei M. The neighbor-joining method: A new method for reconstructing phylogenetic trees. Molecular Biology and Evolution [Internet].1987 [cited 2014 Sep 14];4:406-425.Available from: http://mbe.oxfordjournals.org/content/4/4/406.full.pdf + html

15. Felsenstein J. Confidence limits on phylogenies: An approach using the bootstrap. Evolution [Internet]. 1985 [cited 2014 Jul 20];39:783791. Available from: http://biostat.jhsph.edu/ jleek/teaching/ 2011/754/reading/felsenstein.pdf

16. Takezaki N, RzhetskyA, Nei M. Phylogenetic test of the molecular clock and linearized trees. Molecular Biology and Evolution [Internet]. 2004[cited 2014 Jul 20];12:823-833. Available from: http://mbe.oxfordjournals.org/content/12/5/823.full.pdf+html
17. Tamura K, Nei M. Estimation of the number of nucleotide substitutions in the control region of mitochondrial DNA in humans and chimpanzees. Molecular Biology and Evolution [Internet]. 1993[cited 2014 Jul 20]; 10:512-526. Available from: http://mbe.oxfordjournals.org/content/10/3/512.full.pdf+html

18. Tamura K, Dudley J, Nei M, Kumar S. MEGA4: Molecular Evolutionary Genetics Analysis (MEGA) software version 4.0. Molecular Biology and Evolution [Internet]. 2007[cited 2014 Jul 20];24:1596-1599.Available http://mbe.oxfordjournals.org/content/24/8/1596.full.pdf+html

19. Cai Y-f, Li S-w, Liu Y, Quan S, Chen S, Xie Y-f, Jiang H-z, Wei E$\mathrm{z}$, Yin N-w, Wang L, Zhang R, Huang C-1, He X-H, Jiang M-f. Molecular phylogeny of Ranunculaceae based on internal transcribed spacer sequences. African Journal of Biotechnology [Internet].2009[cited 2014Sep 20];8:5215-5224.Available from: http://www.ajol.info/index.php/ajb/article/view/65953

20. Lawton-Rauh AL, Alvarez-Buylla ER, PuruggananMD.Molecular evolution of flower development.Trends in Ecology \& Evolution.200015:144-149doi: 10.1016/S0169-5347(99)01816-9.

21. Scheinvar L. Taxonomy of utilized opuntias. Agro-ecology, cultivation and uses of cactus pear.BarberaG,Inglese $\mathrm{P}$ andPimientaBarrios E (eds). FAO, Rome, 1995, p 20-27.

22. Pinkava DJ. On the evolution of continental North American Opuntioideae.Succulent Plant Research [Internet]. 2002 [cited 2014 Aug 12];6: 59-98. Available from: http://pt.scribd.com/doc/77301436/Phylogeny-ofOpuntioideae\#scribd

\section{How to cite this article:}

M. C. C. P. de Lyra, M. L. R. B. da Silva, A. C. E. S Mergulhão, C. Mondragon-Jacobo, E. Martínez-Romero. Molecular studies of forage prickly-pear cactus from the semiarid of Pernambuco State - Brazil. J App Biol Biotech. 2015; 3 (02): 001-005. 